\title{
FOR WHOM THE BELL TOLLS: A STORY OF WAR FOR THE CAUSE OF HUMANITY AND DEMOCRACY
}

\author{
Chandra Bahadur K.C., PhD*
}

\begin{abstract}
:
Set against the backdrop of Spanish Civil War (1936-1939), For Whom the Bell tolls provides the firsthand account of that war which Hemingway experienced by serving as a war correspondent. In the novel he takes the side of the Republic for the cause of humanity and democracy. The protagonist Robert Jordan, an American professor from Montana, volunteers his services in the war for anti-fascist cause. He himself thinks that he is inherently antifascist republican, who believes in life, liberty and pursuit of happiness. The novel asserts that the activities shown by the fascists or nationalists were full of selfish and misdirected aggressive impulses. This paper claims that the protagonist and other characters voluntarily involve in the war for the cause of humanity and democracy. The protagonist voluntarily takes part in blowing up the bridge at Guadarrama Mountains near Segovia to stop the Fascists away from the mountains to make the Republican attack successful. He was convinced that the Republicans meant for democratic, civilian, secular order. So he takes part in the war in foreign land for the cause of humanity. This war is related to politics, and the novel is in favour of republican alliance. The novel shows that war is inevitable part for the Republicans for their humanitarian cause. The novel tries to justify the war for the sake of preservation of republican norms like humanity, democracy, freedom, equality, rights of people and brotherhood.
\end{abstract}

Keywords: war, democracy, humanity, republicans, fascists.

Ernest Hemingway's For Whom the Bell Tolls is a famous novel that many researchers and critics have analyzed from various perspectives. Set against the backdrop of Spanish Civil War (19361939), it provides the firsthand account of that war which Hemingway experienced by serving as a war correspondent. War was Hemingway's greatest subject. For him “war groups the maximum of material and speeds up the action and brings out all sorts of stuff that normally you have to wait a lifetime to get" (Muller 2). He tersely evaluated the involvement of the International Brigades. He was openly taking the Republican side for the cause of humanity and democracy. In fact, the Republican government was the second democratically elected government in Spain. In the novel For Whom the Bell Tolls, too, Robert Jordan, an American college teacher from Montana, volunteers his services in the war for the anti-fascist cause. He takes the side of the Loyalists because they are fighting against the rebel army of General Francisco Franco (Oliver 146). In the novel Pilar asks him, "Are you a Communist?" He answers, "No I am an antifascist." (Hemingway 69). In fact he was the descendant of anti-fascist republicans. Jordan says to

Associate Professor of Saraswati Multiple Campus (Humanities Faculty, English Department), Tribhuvan University, Nepal 
himself that "[y]ou believe in Liberty, Equality and Fraternity. You believe in life, liberty and the pursuit of happiness... If this war is lost all of those things are lost" (315). He is staunch supporter of love and dignity. He says to Maria "I love thee as I love liberty and dignity and the rights of all men to work and not be hungry" (361).

Love and war are considered as two chief issues in For Whom the Bell Tolls. Though they seem to be antagonistic to each other, they are perpetuating aspects in literary works. In the novel Jordan meets Maria in the mountains with Pablo's band of guerillas who are staying there after blowing up a train three months earlier. They are in the mountains for guerilla war because it is easy for them to hide from enemies. Maria is, "recovering with Pilar's help from psychological wounds she received when the Falangists (a political wing of the Fascists) entered her hometown, killed her mother and father and the town Mayor, and then gang raped her and several of her friends. When Jordan joins the group, she becomes his lover. Pillar believes that being with Jordan will help Maria overcome her mental wounds" (Oliver146).

In matter of the depiction of the war For Whom the Bell Tolls is a great art work. Professor Paul Sheeran views that "Great art certainly captures and reflects the essence of human conflict and the consequence of war" (51). For Whom the Bell Tolls is also a great art work in a sense that it describes the Spanish Civil War that began in the middle of July, 1936, when a group of generals attempted military coup against the Second Spanish Republic. The war was "against a Republican government committed to social reform, devolution and secularism. Directly or indirectly, the conflict caused about half a million deaths in a population of 24 million" (Lennon 6).

Robert Jordan, the protagonist and an expatriate, is involved in both love and war. His involvement in love is not of great importance in comparison to his involvement in war. He takes part in war supporting the Republican group. He is a staunch supporter of Republican group, and believes on their victory though a republican fighter Pablo has lost belief on his group's power and assumes that opponent group is more powerful than his own. He asserts that the opponents are "always stronger, always better armed. Always with more material" (17).

War is a vague term and it crosses the boundary of the limited territory. According to Oxford Dictionary of Law war is "the legal state of affairs that exists when states use force to vindicate rights or settle disputes between themselves" (532). War may occur between two or more states, or it may occur within a state. If it occurs between internal armed forces of the same nation, it is called civil war. Civil war is an "internal armed conflict between people of the same nation" ("Civil"). Though in civil war the conflict is between people of the same nation, they may be assisted by people outside the nation.

Why do wars occur? This is the great question that people always raise and try to answer. In Lilienstern's view "the war as a whole always has a final political purpose, that means that war is undertaken and conducted in order to realize the political purpose upon which the state's [leading] powers have decided in view of the nation's internal- external conditions" (quoted in Clausewitz $\mathrm{xv}$ ). Kenneth Waltz says that "the locus of the important war results from selfishness, from misdirected aggressiveness impulses, from stupidity" (16). This explanation asserts that men behave badly because they are bad by nature. The selfish and aggressive nature of men creates conflicts and wars occur. The conflict groups are the essential parts of social and political affairs. In the Spanish Civil War the conflict groups were nationalists and the Republicans. The troops led by General Francisco Franco revolted against newly elected "popular front" government. Franco's 
supporters came to be known as the nationalists or Falangists, whereas the newly elected group was known as the Republic. The defenders of the newly elected government were also called the Loyalists. Both of the groups had their own reasons for the war. The war was of great significance for "those Spaniards who had hoped the Republic would usher in an unprecedented era of social justice and modernization, and for others who regarded [the Republic government] as a revolutionary and irreligious assault of Spanish tradition" (Lannon 6).

The novel asserts that the activities shown by the fascists or nationalists were full of selfish and misdirected aggressive impulses. The protagonist and other characters who are fighting from the side of the Republicans believe that the fascists are full of selfish and misdirected aggressive impulses. This paper claims that the protagonist and other characters voluntarily involve in the war for the cause of humanity and democracy.

In the novel For Whom the Bell Tolls Franco's group is named as the Fascists and the popularly elected groups are referred to as the Republic. “The nationalists, or Falangists, as Franco's supporters came to be known, were backed by large landowners, the clergy, and eventually by increasing number of middle class. The Loyalists, defenders of the elected republic government, drew their support from urban areas and the peasant class" (Quinn 299). In this way during the war the Spanish population was divided into two clear-cut factions. Every war is fought for certain causes. In Spanish Civil War both groups "were convinced that they were fighting for civilization against the powers of darkness" (Turnbull 5) "On Franco's side, the evidence of statements by generals at the time of the July rising reveals that their chief-pre-occupations were national unity, and law and order. They wanted to end the Republican's experiments with devolution, and to curb the waves of street violence, land occupations and strikes that seemed to be swelling out of control" (Lannon 7). On the other hand, the Republicans believed that men and women could be equal, they believed that "women could be politicians, public speakers, even soldiers, the most traditionally masculine of all occupations" (69). They meant for democratic, civilian secular order. The term Republic implied "a shift in public policy in favour of the working masses and the poor" (16). "The Republic meant, for those who cheered its arrival, a democratic, civilian secular order" (16). But the Nationalists believed on gender roles in society. Hemingway in the novel For Whom the Bell Tolls takes the stance towards the Republican.

In For Whom the Bell Tolls the action takes place within four days in Guadarrama Mountains near Segovia, northwest of Madrid. It describes the explosion of the bridge of strategic importance in Guadarrama Mountains of central Spain to keep the Fascists away from the mountains. The protagonist "Robert Jordan, a young American professor and an expert dynamiter, comes to the camp of a band of loyalist guerrillas with an assignment from general headquarters to blow up [the] strategically important bridge" (Quinn 301). He was an expert "who knew how to blow any sort of bridge that you could name and he had blown them of all sizes and constructions" (Hemingway 6-7). He gets the order from General Golz to stall the fascists after the loyalist attack. Voluntarily Robert takes part in this arduous job of the destruction for the cause of liberty and the right of the people, mainly because the progressive issues like "Land reform, jobs, improved wages and better public provision for health and particularly education were essential items on the Republican agenda" (Lannon 16).

For Whom the Bell Tolls is a fictional account of the Spanish Republican guerrilla warfare, and it gave a vivid picture of the Spanish Civil war to its American readers. It describes the activities 
done mainly by the Republicans for betterment of Spanish people. The novel "emerges from the bloody and tumultuous history of the twentieth century" (Stoltzfus 190). Though the novel is set in the backdrop of Spanish Civil War, it shows international concern for democracy by stopping the advance of Fascism in Europe. It intermixes political commitment and art. The protagonist Robert Jordan joins to the International Brigades to take part in Spanish Civil War to support the Republican (the ruling group) for the sake of democracy and betterment of humanity. He voluntarily takes part in the war because the republican spirit is in his blood. The republicanism is the political concept that leads people away crossing the national boundaries. He says "My father was also a republican all his life. Also my grandfather" (Hemingway 69). His grandfather had fought in the American Civil War (1861-1865) with other major figures like Quantrill, John Mossy, Grant, Sherman, Stonewell Jackson, Jeb Stuart, Phil Sheridan, McClellan and Killy-theHorse-Kilpatrick. He thinks of himself "You had read on and studied the art of war ever since you were a boy and your grandfather had started you on the American Civil War. Excellent that Grandfather always called it the war of the Rebellion.... Your grandfather fought four years in our Civil War and you are just finishing your first year in this war" (347-348).

Fifty-two year old Russian officer General Golz also involves in the civil war. In the novel we find him planning to attack the fascists to keep them away from Guadarrama Mountains. Golz has a victorious history. He is a person "who had captured the gold train that winter with Lucaz in Siberia. Golz who had fought against Kolchak, and in Poland, in the Caucasus. In China, and here since the first October" (438). He is the communist commander of the $14^{\text {th }}$ and $35^{\text {th }}$ International Brigades of the Republican army. As he is attacking to the front, he gives Robert Jordan order for blowing up the bridge. He is fighting in foreign country for republican cause.

For Sinclair Lewis the novel is a masterpiece that is "crystallization of the world revolution that began long ago- perhaps in 1776, perhaps in 1848- and that will not cease till the human world has either been civilized or destroyed- perhaps in 1976, perhaps in 2848" (quoted in Oliver 146147). Lewis further remarks, "When the reader, identifying himself with Robert Jordan, actually smells the fighting, then freedom may become an activity to live for, to die for, and brotherhood may become inevitable" (quoted in Oliver 147). The brotherhood becomes inevitable in the novel. Robert Jordan at last sends all others away though he is seriously wounded to save them from the attack of the enemy group.

Death becomes very near during the war worldwide. In one conversation informing about foreign dynamiter Kashkin, Robert says, "He is dead since April". In response Pablo says "That is what happens to everybody" (Hemingway 17). Robert says, "Dying is only bad when it takes a long time and hurts so much that it humiliates you" (487). At last, lieutenant Berrendo, a fascist officer appears near him. "He could feel his heart beating against the pine needle floor of the forest" (490). For his conviction sense of death becomes minor in comparison to the conviction.

The novel tells something about discipline, obeyance and faith during the time of war. As Pablo refutes to obey his order, Jordan tells him, "I come only for my duty. I come under orders from those who are conducting the war. If I ask you to help me, you can refuse and I will find others who will help me" (18). In the mountains they are working for the republic with great faith and with the hope to win the war. Pilar says, "I put great illusion in the Republic. I believe firmly in the Republic and I have faith. I believe in it with fervor as those who have religious faith believe in the mysteries" (96). Jordan's great faith is in blowing up the bridge because he thinks "For us 
will be the bridge and the battle, should there be the one" (46). He tells himself, "There is a bridge and that bridge can be the point on which the future of human race can turn" (46). Discipline and obeying of orders are essential ingredients to win any war. Ansolmo who is a mature guerilla fighting for the cause of democracy realizes the weaknesses of his side. So he says, "All through this war we have suffered from a lack of discipline and from disobeying of orders" (200). People have faith on certain beliefs, and they fight for it with strong discipline.

The novel also reports the victorious republican activities. War is fought for certain conviction, but it also makes people brutal. "On the second day Pilar tells Jordan about the beginning of the Republican movement when she witnessed the ugly killing of twenty fascists in their hometown" (Oliver 147). Pilar reports that when the Civiles (the Fascists) surrendered at the barracks, "Pablo had surrounded it in the dark, cut the telephone wires, placed dynamite under one wall and called on the guardia civil to surrender. They would not. And at daylight he blew the wall open. There was fighting. Two civiles were killed. Four were wounded and four surrendered" (Hemingway 105). Pablo and others had finished the wounded. Pablo charged them as the murderers of the peasants. Then he made the four arrested to kneel on the wall and shot each in turn on the head with the pistol. That morning they had won the town. There were more than twenty other fascists. Pablo had not shot them. He "had them beaten to death with flails and thrown from the top of the cliff into the river" (108). The people in the plaza killed them cruelly. They hit the Mayor Don Benito with flails. "They beat him until he fell and the man who had struck first called to others to him... and with his face in the dust of the plaza, they dragged him over the wall to the edge of the cliff and threw him over and into the river" (114). Similarly Don Federico Gonzalez, who owned the mill and feed store and was a fascist of the first order, came to the plaza. "He ran fast through the double line with flails falling on his back and shoulders until he fell and those at the end of the line picked him up and swung him over the cliff" (116). Then Don Ricardo Montago volunteered to be killed. He insulted the Republic saying, "Down with the miscalled Republic and I obscenity in the milk of your fathers" (117). They clubbed him to death very quickly. Then came the turn of Don Faustino Revero, son of a lawyer. He was thrown alive to the river. The people in line were now full of thirst to kill because it is true that "To kill gives much thirst" (121). The next turn was of Don Guillermo martin, owner of the flails store, a fascist. The drunkard beat him with flails. The cruelty and ugly actions were thought necessary to preserve the Republic. The fascists were killed indecently and with mockery. Next turn was of Don Anastasio Rivas, a grain buyer and an agent of several insurance companies and also loaned money at high rates of interests. He was beaten to death by the mob against the stone flags of the paving of the arcade. Now lines change into the mob. They move into the hall and kill the remaining fascists including the priests and carry them putting on the cart and throw them into the river. But three days later the fascists take the town.

During the war cruel activities are done from both sides. The novel also mentions the cruel actions done by the fascists. Jordan Pilar and Maria go to the camp of El Sordo, the commander of one of the guerilla group. They meet Joaquin, a guard, at the gate who has a bad experience of war because the fascists had shot his father, his mother, his sister and his brother-in-law in Valladilid, his home town, in barbarous way. "When the fascists purified the town they shot first the father. He had voted socialist. Then they shot the mother. She had voted the same" (144). Joaquin was not only a person who has lost his relatives, Jordan has heard the story of the loss of mother, father and other relatives from the mouth of many people. Maria has also the similar 
experience. She says, "My father was the Mayor of the village and an honourable man. My mother was an honourable woman and a good Catholic and they shot her with my father because of the politics of my father who was a Republican. I saw both of them shot and my father said, 'viva la Republican', when they shot him standing against the wall of the slaughter house of our village" (364).

In Jordan's view, “The first thing was to win the war. If we did not win the war everything was lost...He gave absolute loyalty and as complete performance as he could give while he was serving" (142). It is the sense of internationalism. The political faith on humanity and liberty does not limit only within a certain territorial boundary. Robert Jordan fought in the war because

[I]t had started in the country that he loved and he believed in the republic and that if it were destroyed life would be unbearable for all those people who believed in it. He was under communist discipline for the duration of war. Here in Spain the communists offered the best discipline and the soundest and the sanest for the prosecution of the war... [In] the conduct of the war, they were only party whose program and whose discipline he could respect (170).

While blowing up the bridge Jordan says "as long as we can hold them here we keep the fascists tied up. They cannot attack any other country until they finish with us and they can never finish with us. If the French help at all, if only they have the frontier open and if we get planes from America they can never finish with us. Never, if we get anything at all. These people will fight forever if they're well-armed" (449). Jordan has fear of spreading the fascist ruling in many other countries, so he wants to defeat them in Spain to finish them there.

During the time of war all friends become a family. When Joaquin cries remembering his family members, Maria says, "I am thy sister. And I love thee and thou hast a family. We are all thy family" (145). It is the sense of brotherhood that cross national and cultural boundaries.

War is so cruel. Cruelty is inevitable nature of war. When war is fought cruelty appears. Kashkin and Roberto were returning after blowing up a train. They were returning in the dark when they "encounter a fascist patrol and as [they] ran he was shot high in the back but without hitting any bone except the shoulder blade. He travelled quite a long way, but with the wound was unable to travel more. He was unwilling to be left behind and [Jordan] shot him" (159). When Jordan becomes wounded while returning after blowing up the bridge, and he becomes unable to keep up his journey, Agustin also asks him he will shoot if he likes. After killing Sordo and his soldiers in the hill fascist Lieutenant Berrendo "felt only the hollowness that comes after action. He was thinking: taking the heads is barbarous. But proof and identification is necessary" (337). Fernando says "What barbarians these fascists are!... We must teach them we must take away their planes, their artillery and teach them dignity" (339).

War is fought for certain conviction. While returning after blowing up the bridge, Robert Jordan is seriously wounded. He tells other companions to leave him there and go to the Gredos. As Agustin does not want to leave him alone in the jungle, he replies "In war there are many things like this" (484). Agustin replies, "War is a bitchery" (484). After all others go away to Gredos leaving him in the jungle alone, Jordan thinks "I have fought for what I believed in for a year now. If we win here we will win everywhere. The world is a fine place and worth the fighting for and I hate very much to leave it. And you had a lot of luck, he told himself, to have had such a 
good life. You've had just as good a life as Grandfather's though not as long. You've had as good a life as any one because of these last days" (485-486).

While watching activities at the bridge, Anselmo thinks that he has worked well for the Republic. He says, "I have worked hard for the good that we will all share later" (206). They have the faith on the Republic because "everything can be done under the Republic" (215).

Every war is fought to kill the opponents. Robert says "Every fascist dead is a fascist less" (287). He has the belief that his group should win the war because if they "do not win this war there will be no revolution nor any Republic nor any thou nor any me nor anything" (295). He further says, "You see that we are working for one thing. To win the war. Unless we win, all other things are futile. Tomorrow we have a thing of great importance. Of true importance. Also we will have combat. In combat there must be discipline. For many things are not as they appear. Discipline must come from trust and confidence" (302). Anselmo also believes that they should win the war. As Agustin plans to shoot "the anarchists and the communists and all the canalla except the good Republicans," Anselmo believes that they should win that war and they should shoot nobody. He also plans about ruling after the war. He says, "We should govern justly and that all should participate in the benefits according as they have striven for them. And that those who have fought against us should be educated to see their error... That we should none. Not even the leaders. That they should be reformed by work" (295-296).

The revolution had shattered the lives of innocent people like Maria. Jordan plans to care her seriously by taking her with him after the blowing of the bridge. But unfortunately he loses his life at the blowing of the bridge. In war people are compelled to take part in war for life. Andres says, "The fascists attacked and made our decision for us. We fight to live" (384). Andres further says, "But you have no house and no courtyard to your no-house, he thought. You have no family but a brother who goes to battle tomorrow and you own nothing but the wind and the sun and an empty belly" (384). It is true that war shatters the lives and families of people.

The novel describes the active involvement of the Soviet government and its people in the Spanish Civil War in the name of liberation of Spain form the capturing of the fascists. The Spanish government had paid much to the Soviet government for its help in the war. "On 16 October 1936, the day the first major Russian arms shipment reached Spain, the Soviet leader Joseph Stalin sent Jose Diaz, Secretary General of the Spanish Communist Party, the PCE the following: [...] the liberation of Spain ... is not the private concern of the Spain but the general concern of all advanced and progressive humanity" (171). In Gaylord's hotel in Madrid the Russians had taken over. Gaylord's was the place where one could meet famous peasant and worker Spanish Commanders who had sprung to arms from the people at the start of the war without any previous military training and found that many of them spoke Russians. "They were peasants and workers. They had been active in the 1934 revolution and had to flee the country when it failed and in Russia they had sent them to the military academy and to the Lenin institute the Comintern maintained so they would be ready to fight the next time and have the necessary military education to command" (237).

At Gaylord's many Russian officers stayed and made strategic plan for war. There stayed Valentin Gonzalez, an ex-sergeant in the Spanish Foreign legion who had deserted and fought with Abd el Krim. "He was a wonderful Brigade commander though in a situation where it looked as though everything was lost" (238). There also stayed the simple stonemason Enrique Lister 
Galicia, who now commanded a division and who talked Russian, too. The cabinet worker, Juan Modesto from Andalucia who had just been given an army Corps also stayed in the hotel. "He was the most trusted of the young soldiers by the Russians because he was a true party man 'a hundred percent' they said, proud to use the Americanism" (238).

At Gaylord's were also Kleber, Lucasz, Hans and the Hungerian officer Gall who had done a fine job of their share in the defense of Madrid with the International Brigades. They had fought there with the true comradeship of the revolution. The Madrid Palace had been turned into the International Brigade Headquarters in the capital. General Gall is a Hungarian officer, an unpopular commander in the International Brigades, fighting for the Republicans. Hemingway also refers the real figure Andre Marty (1886-1955) who was a French Communist commissar and head of the International Brigades during the Spanish Civil War. He came from the central committee of the French Communist party. He was "one of France's great modern revolutionary figures who had led mutiny of the French Navy in the Black Sea" (434). He had high political place in the International Brigades. By observing the residents of Gaylord's hotel, we can know the involvement of people from different nations during the Spanish Civil War.

The Russian journalist Karkov was associated with Pravda and had direct communication with Stalin. His view on war and army is that anarchy cannot win a war. All must have certain level of political development, and they must know the cause and importance of their fighting. They must believe in fight and must accept discipline. He says, "We are making a huge conscript any without the time to implant the discipline that a conscript army must have, to behave properly under fire. We call it a people's army and it will not have the iron discipline that a conscript any needs. You will see. It is a very dangerous procedure" (255).

The Spanish War was of great importance for the Soviet press. It "published daily reports accusing international fascism, meaning Germany and Italy, of fomenting and sustaining the war" (Payne 12). "The first Pravda editorial on the Spanish war on August I, [1936], was headed 'Fascism means war, Socialism means peace"' (126).

The discussion shows that the Spanish Civil War, the main subject of the novel For Whom the Bell Tells, was the war which affected not only Spain but many other countries. The domestic politics of Spain affects the international relations. German and Italian governments help the Fascists, whereas the Soviet government and many people from different countries are voluntarily taking the side of the Republican for the cause of democracy and democracy. . The nations like France and Britain remain neutral, but the people of these nations take part in the war independently. The protagonist, the American dynamiter, voluntarily takes part in blowing up the bridge at Guadarrama Mountains near Segovia to stop the Fascists away from the mountains to make the Republican attack successful. He is the believer of Liberty, Equality and Fraternity. He was convinced that the Republicans meant for democratic, civilian, secular order. So he takes part in the war in foreign land for the cause of humanity. This war is related to politics, and the novel is in favour of republican alliance. Most part of the novel is full of the description of activities done by the supporters of the Republican side. It shows that war is inevitable part for the Republican for their humanitarian cause, whereas it shows the activities shown by the Fascists being full of selfish and misdirected aggressive impulses. The novel also explains the involvement of Russian people and government in the Spanish Civil War. The novel tries to justify the war for the sake of preservation of republican norms like humanity, democracy, freedom, equality, rights 
of people and brotherhood. When it is fought for certain political causes, it may draw the involvement of the people of many countries.

\section{Works Cited}

“Civil War”. Black's Law Dictionary. Edited by Brian A. Garner, $7^{\text {th }}$ Edition. St. Paul, West Group, 1999.

Clausewitz, Coal Van. On War. Oxford University Press, 2007.

Hemingway, Ernest Miller. For Whom the Bell Tolls. Oxford University Press, 1996.

Lannon, Francis. The Spanish Civil War 1936-1939. Osprey Publishing Limited, 2002.

Muller, H. Gilbert. Hemingway and the Spanish Civil War: The Distance Sound of Battle.

Palgrave Macmillan, 2019.

Oliver, Charles M. Critical Companion to Ernest Hemingway. Facts on File,

2007.

Quinn, Edward. History in Literature. Facts on File Inc., 2004.

Sheeran, Paul. Literature and International Relations: Stories in the Art of Diplomacy. Ashgate Publishing Limited, 2007.

Stoltzfus, Ben. "Hemingway, Malraux and Spain: For Whom the Bell Tolls and L'espoir." Comparative Literature Studies, vol. 36, no. 3, 1999, pp. 179-194. JSTOR, JSTOR, www.jstor.org/stable/40247180. Web. 6/10/2018.

Turnbull Patrick. The Spanish Civil War 1936-39. Reed International Books Ltd, 1978.

Waltz, Kenneth. Man, State and War. Columbia University Press, 1959.

"War". Oxford Dictionary of Law. Edited by Elizabeth A. Martin, $5^{\text {th }}$ ed. Oxford University Press, 2002. 